\title{
Concentration of Gadolinium-Diethylene Triamine Pentaacetic Acid in Human Kidney Study on Proper Time for Dynamic Magnetic Resonance Imaging of the Human Kidney on Low and High Magnetic Fields
}

\author{
Masayuki Takeda, Yasushi Katayama, Toshiki \\ Tsutsui, Takeshi Komeyama, Takaki Mizusawa, \\ Toshiki Tanikawa and Shotaro Sato \\ Department of Urology, Nïgata University School of \\ Medicine, Niigata 951
}

\begin{abstract}
Takeda, M., Katayama, Y., Tsutsui, T., Komeyama, T., Mizusawa, T., Tanikawa, T. and Sato, S. Concentration of Gadolinium-Diethylene Triamine Pentaacetic Acid in Human Kidney - Study on Proper Time for Dynamic Magnetic Resonance Imaging of the Human Kidney on Low and High Magnetic Fields. Tohoku J. Exp. Med., 1993, 171 (2), 119-128_ Although Gadolinium diethylene triamine pentaacetic acid (Gd-DTPA) has been used as a contrast material in magnetic resonance imaging, it is known that contrast enhancement effect disappears if the concentration of Gd-DPTA increases beyond some levels. In this study, to evaluate the proper pulse sequences for dynamic magnetic resonance imaging (MRI) in the human kidney, the concentration of Gd-DTPA was quantitatively measured by inductively coupled plasma (ICP) emission spectrometry in human biological samples after administration of Gd-DTPA, and the signal intensity of MRI is the solutions of several concentrations of Gd-DTPA was measured. The results were; 1 . In using a low magnetic field apparatus, signal intensity linearly correlated with the concentration of Gd-DTPA between 0 and $2.0 \mu \mathrm{mol} / \mathrm{g}$ under saturation recovery sequences (flip angle was $60^{\circ}$ or $90^{\circ}$ ). Using a high magnetic field apparatus, signal intensity linearly correlated with the concentration of Gd-DTPA between 0 and 2.0 or $3.0 \mu \mathrm{mol} / \mathrm{g}$ under spin echo or gradient-echo sequences. 2. Gd-DTPA concentration of the renal cortex ranged from 0.132 to $0.152 \mu \mathrm{mol} / \mathrm{g}$ tissue at 5 min after intravenous injection of Gd-DTPA $0.05 \mathrm{mmol} / \mathrm{kg}$ body weight in 7 patients with adrenal tumor or renal cell cancer, and 1 patient with both urinary bladder cancer and prostatic cancer. Seven of them showed normal renal function and the other had renal insufficiency (GFR 25 $\mathrm{ml} / \mathrm{min} / 1.48 \mathrm{~m}^{2}$ ). Gd-DTPA concentrations of renal medulla and renal cell cancer tissue were 0.123 and $0.108 \mu \mathrm{mol} / \mathrm{g}$ tissue, respectively, at $5 \mathrm{~min}$ after itravenous injection of Gd-DTPA $0.05 \mathrm{mmol} / \mathrm{kg}$ body weight. These results suggest that the signal intensity of renal cortex, renal medulla, and renal cell cancer tissue may linearly correlate with Gd-DTPA concentration of tissues at 5 min after
\end{abstract}

Received February 24, 1993; revision accepted for publication September 7, 1993. Correspondence and reprint requests to: Masayuki Takeda, M.D., Department of Urology, Niigata University School of Medicine, Asahi-machi 1, Niigata 951, Japan. 
intravenous injection of Gd-DTPA $0.5 \mathrm{mmol} / \mathrm{kg}$ body weight.— tissue distribution; gadolinium-diethylene triamine pentaacetic acid; dynamic magnetic resonance imaging; kidney

With recent advances in the techniques and apparatus of magnetic resonance imaging (MRI), MRI has become one of the most important diagnostic methods of renal diseases (Goldman et al. 1990; Kreesel 1990; Barbaric 1991). MRI has become valuable in the diagnosis of high stage renal cell cancer (Hricak et al. 1985; Hricak et al. 1988), especially in cases with tumor thrombus into the vena cava. However, it is not as valuable as x-ray CT (CT) in cases with lower stage cancers (Fein et al. 1987), because the relaxation time of normal renal parenchyma is almost the same as that of renal cell cancer (Hricak et al. 1983). Apart from these weakpoints, MRI has advantages, such as absence of radiation exposure and any optional image plane (Kreesel 1990). Because most renal cell cancer lesions show hypervascular findings, and contrast enhanced MRI (dynamic MRI) has become possible due to the development of contrast media, Gadolinium-diethylene triaminepentaacetic acid, Gd-DTPA (Carr et al. 1984), MRI may be of use even in cases with low stage renal cell cancer. Gd-DTPA has the effect of shortening relaxation time, consequently lenghtening signal intensity (S.I.) on T1 weighted images (T1W1). Dynamic MRI has been said to be useful and more valuable than redioisotope (RI) renography in assessing the function of the kidney (Takeda et al. 1990; Togami et al. 1991). Signal intensity increases with increased concentration of Gd-DTPA, on the contrary, it decreases with the increase in the concentration of Gd-DTPA beyond a point. This is called "T2 shortening effect" (Goldstein et al. 1984). In several organs, especially in the renal medulla, Gd-DTPA may accumulate and the concentration of Gd-DTPA may become higher, and the "T2 shortening effect" may occur. In this report, the relationship between S.I, and the concentration of Gd-DTPA was examined in several pulse sequences and in both low and high magnetic fields to evaluate the presence of "T2 shortening effect", and the concentration of Gd-DTPA in the human kidney at the early stage after administration of a normal dose of Gd-DTPA to determine the value of dynamic MRI in the human kidney.

\section{Patients and Methods}

Methods for examination of the relationship between the concentration of Gd-DTPA and signal intensity (S.I.).

Gd-DTPA (Magnevist, Schering Japan Co., Ltd., Osaka) was diluted with physiologic saline at 14 different concentrations, $0,0.1,0.3,0.5,1.0,1.5,2.0,2.5,3.0,4.0,5.0,7.5,10.0$, and $100 \mu \mathrm{mol} / \mathrm{g}$. The volume of each Gd-DTPA solution was $25 \mathrm{ml}$, and each sulution was put into a culture flask (Becton \& Dickinson Co. Ltd., Los Angels, CA, USA). Because this type of plastic flask causes little proton magnetic resonance phenomenon, measurement of S.I. is not influenced by signal due to the flask. Types of MRI apparatus (low magnetic field, and high magnetic field) were Mark-J (Siemens Asahi Meditech Co., Ltd., Tokyo) as 
a low magnetic field imager and Signa advantage (Yokogawa Medical Co., Ltd., Tokyo) as a high field imager. Mark-J operates at 0.1 tesla with a resistive conducting magnet, and Signa operates at 1.5 tesla with a super-conducting magnet. Pulse sequences of Mark-J were saturation recovery (Keevil et al. 1992; SR; TR=100 msec, TE $=12 \mathrm{msec}$, number of secitations $=2$, matrix size $=256 \times 256$, flip angle $=60^{\circ}$ or $\left.90^{\circ}\right)$. Pulse sequences of Signa Advantage were spin echo $(\mathrm{TR}=500 \mathrm{msec}, \mathrm{TE}=11 \mathrm{msec}$, number of excitations $=2$, matrix size $=256 \times 256)$ and one type of gradient-echo sequence (Spoiled Gradient Recoiled Acquisition in the Steady State (Edelman et al. 1990; SPGR, TR=21 msec, TE $=13 \mathrm{msec}$, number of excitations $=2$, flip angle $=45^{\circ}$, matrix size $=256 \times 256$ ). All pulse sequences show $\mathrm{T} 1$ weighted images. After coronal MRI, which was the largest section of the bottle containing Gd-DTPA solution, was taken under the above pulse sequences, S.I. was calculated by making region of interests (ROI) on Gd-DTPA solution on the image display (Fig. 1).

\section{Patients and methods of measurement of Gd-DTPA concentration}

Eight patients ( 2 primary aldosteronism, 5 renal cell cancer, and 1 urinary bladder cancer) who were treated in Niigata University Hospital were examined in this study after informed consent was obtained from each (Table 1). During surgery, specimens $(0.1-7.0 \mathrm{~g})$ of several organs were collected after Gd-DTPA $0.05 \mathrm{mmol} / \mathrm{kg}$ body weight was intravenously injected. These specimens were frozen at $-80^{\circ} \mathrm{C}$ as soon as possible, and the concentration of Gd-DTPA was measured by ICP emission spectrometry (Subramanian and Meranger 1982) within 1 month after operation. Details of the analysis were as follows;

After the specimen was homogenized, the homogenate was diluted 10 fold by adding distilled water. The diluted specimens were centrifuged at 3,500 RPM for 15 min, and the supernatant was filtered with a membrane filter $(0.8 \mu \mathrm{m}$ pore size $)$. The filtered solution was measured by ICP emission spectrometry using SPS 1200A (Seiko Electronics Co. Ltd., Tokyo).

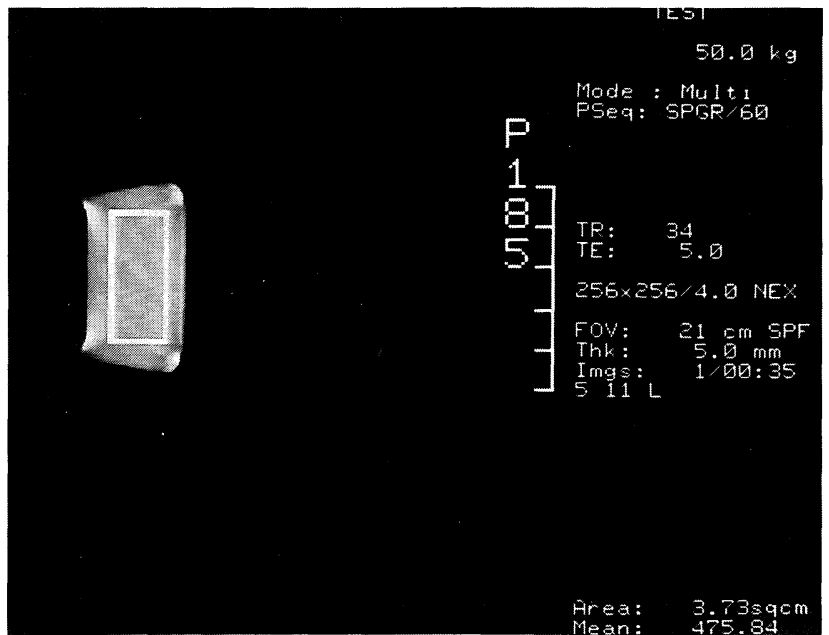

Fig. 1. Magnetic resonance imaging and measurement of signal of intensity Gd-DTPA solution in plastic bottle. 


\section{RESULTS}

Correlation between concentration of Gd-DTPA solution and S.I.

In the low magnetic field apparatus (Mark-J with 0.1 tesla resistive conducting magnet), concentration of Gd-DTPA and S.I. linearly correlated between 0 and $2.0 \mu \mathrm{mol} / \mathrm{g}$ under SR sequences $\left(\gamma=0.89\right.$; flip angle $=90^{\circ}, \gamma=0.86$; flip angle $\left.=60^{\circ}\right)$. Beyond Gd-DTPA $2.0 \mu \mathrm{mol} / \mathrm{g}$, S.I. decreased with the increase of Gd-DTPA concentration (Fig. 2). In the high magnetic field apparatus (Signa Advantage with 1.5 tesla super-conducting magnet), concentration of Gd-DPTA solution and S.I. linearly correlated between 0 and $3.0 \mu \mathrm{mol} / \mathrm{g}$ under spin echo sequence $(\gamma=0.90)$ and under SPGR sequence $(\gamma=0.97)$. Beyond $2.0 \mu \mathrm{mol} / \mathrm{g}$ under SPGR sequence and beyond $3.0 \mu \mathrm{mol} / \mathrm{g}$ under SPGR sequence, S.I. decreased with increasing Gd-DTPA concentration (Fig. 2, Table 2).

\section{Gd-DTPA concentration of human tissue}

Table 3 shows results and details of the patients. Seven specimens of renal cortex, 5 specimens of renal medulla, 5 specimens of renal cell cancer at 5 min after injection of Gd-DTPA, and other tissues collected later were obtained. Glomerular filtration rate (GFR) ranged from 25 to $105 \mathrm{ml} / \mathrm{min} / 1.48 \mathrm{~m}^{2}$ body surface area, and the concentration of Gd-DTPA of the renal cortex ranged from 0.132 to $0.185 \mu \mathrm{mol} / \mathrm{g}$ tissue. The concentration of Gd-DTPA of the renal medulla ranged

TABle 1. Patients

\begin{tabular}{|c|c|c|c|c|}
\hline No. & $\begin{array}{c}\text { Age } \\
\text { (years) }\end{array}$ & Sex & Diseases & $\begin{array}{c}\mathrm{GFR}^{\mathrm{a}} \\
\left(\mathrm{ml} / \mathrm{min} / 1.48 \mathrm{~m}^{2}\right)\end{array}$ \\
\hline 1 & 38 & M & $\begin{array}{l}\text { Primary aldosteronism } \\
\text { of the right adrenal } \\
\text { gland }\end{array}$ & 25 \\
\hline 2 & 57 & $\mathrm{~F}$ & $\begin{array}{l}\text { Primary aldosteronism } \\
\text { of the left adrenal } \\
\text { gland }\end{array}$ & 75 \\
\hline 3 & 42 & $\mathrm{M}$ & $\begin{array}{l}\text { Left renal cell } \\
\text { cancer }\end{array}$ & 105 \\
\hline 4 & 55 & M & $\begin{array}{l}\text { Urinary bladder } \\
\text { cancer, prostatic } \\
\text { cancer }\end{array}$ & 95 \\
\hline 5 & 58 & M & $\begin{array}{l}\text { Right renal cell } \\
\text { cancer }\end{array}$ & 82 \\
\hline 6 & 62 & $\mathrm{~F}$ & $\begin{array}{l}\text { Right renal cell } \\
\text { cancer }\end{array}$ & 91 \\
\hline 7 & 67 & $\mathrm{M}$ & $\begin{array}{l}\text { Left renal cell } \\
\text { cancer }\end{array}$ & 71 \\
\hline 8 & 51 & $\mathrm{~F}$ & $\begin{array}{l}\text { Left renal cell } \\
\text { cancer }\end{array}$ & 98 \\
\hline
\end{tabular}

${ }^{\mathrm{a}} \mathrm{GFR}$, Glomerular filtration rate. 

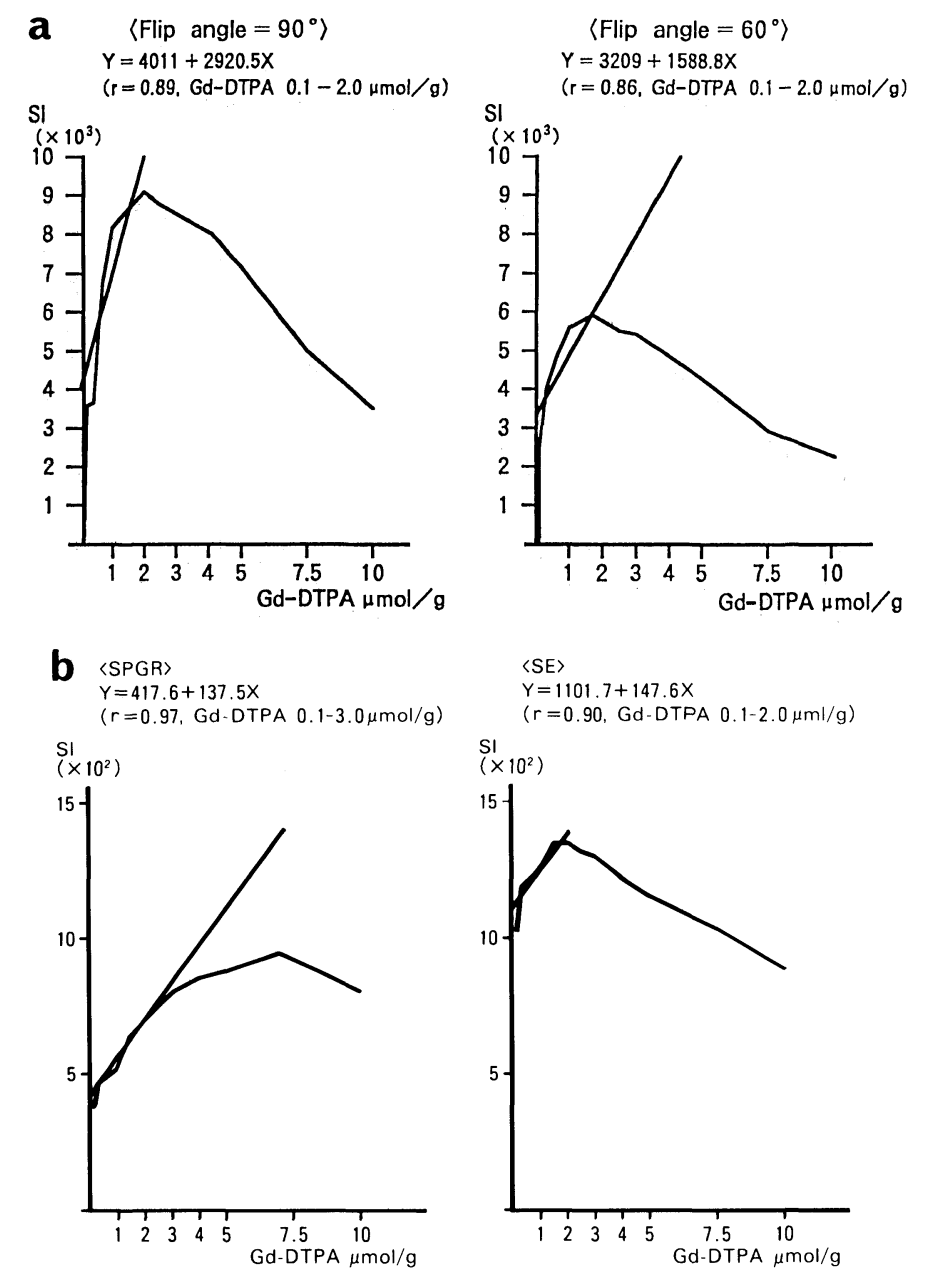

Fig. 2. Signal intensity and Gd-DTPA concentration.

a: Under saturation recovery sequences using low magnetic field apparatus.

b: Under ordinary spin-echo and SPGR sequences using high-magnetic resonance apparatus.

from 0.123 to $0.177 \mu \mathrm{mol} / \mathrm{g}$ tissue. The concentration of Gd-DTPA of the renal cell cancer tissue ranged from 0.105 to $-.0 .151 \mu \mathrm{mol} / \mathrm{g}$. The other specimens were adipose tissue, detrusor muscle of urinary bladder, prostate, and ileum obtained from $10 \mathrm{~min}$ to 10 hours after Gd-DTPA injection. Gd-DTPA concentration of these specimens ranged from 0.011 to $0.026 \mu \mathrm{mol} / \mathrm{g}$. According to our result, Gd-DTPA concentration of all specimens should correlate linearly with S.I. of MRI using both low and high magnetic field apparatus and "T2 shortening effect" should not occur. 
TABLE 2. Concentration of Gd-DTPA solution and signal intensity on each pulse sepuence and using low and high magnetic field apparatus

\begin{tabular}{|c|c|c|c|c|}
\hline \multirow{3}{*}{$\begin{array}{c}\text { Gd-DTPA } \\
\text { conc. } \\
(\mu \mathrm{mol} / \mathrm{g})\end{array}$} & \multicolumn{4}{|c|}{ Pulse sequences and signal intensity } \\
\hline & \multicolumn{2}{|c|}{ Low magnetic field } & \multicolumn{2}{|c|}{ High magnetic filed } \\
\hline & $\begin{array}{c}\text { SRa } \\
\left(\mathrm{FA}-60^{\circ}\right)\end{array}$ & $\begin{array}{c}\mathrm{SR} \\
\left(\mathrm{FA}=90^{\circ}\right)\end{array}$ & $\mathrm{SE}$ & SPGR \\
\hline 0 & $108 \pm 53$ & $273 \pm 102$ & $94 \pm 4$ & $203 \pm 32$ \\
\hline 0.1 & $2469 \pm 103$ & $3686 \pm 263$ & $379 \pm 12$ & $1031 \pm 21$ \\
\hline 0.3 & $3608 \pm 204$ & $3622 \pm 99$ & $464 \pm 17$ & $192 \pm 32$ \\
\hline 0.5 & $0760 \pm 106$ & $6861 \pm 169$ & $475 \pm 15$ & $1206 \pm 27$ \\
\hline 1.0 & $5500 \pm 137$ & $8153 \pm 151$ & $518 \pm 18$ & $1270 \pm 30$ \\
\hline 1.5 & $5718 \pm 110$ & $8424 \pm 151$ & $633 \pm 20$ & $1352 \pm 30$ \\
\hline 2.0 & $5902 \pm 202$ & $9090 \pm 185$ & $700 \pm 23$ & $1354 \pm 27$ \\
\hline 2.5 & $5501 \pm 111$ & $8836 \pm 247$ & $758 \pm 24$ & $1327 \pm 31$ \\
\hline 3.0 & $5455 \pm 116$ & $8590 \pm 236$ & $804 \pm 24$ & $1310 \pm 25$ \\
\hline 4.0 & $4902 \pm 124$ & $8014 \pm 260$ & $859 \pm 24$ & $1230 \pm 29$ \\
\hline 5.0 & $4376 \pm 85$ & $7168 \pm 135$ & $883 \pm 27$ & $1169 \pm 28$ \\
\hline 7.5 & $3155 \pm 117$ & $5000 \pm 160$ & $958 \pm 22$ & $965 \pm 25$ \\
\hline 10.0 & $2164 \pm 103$ & $3535 \pm 197$ & $819 \pm 26$ & $893 \pm 20$ \\
\hline 100.0 & $2478 \pm 80$ & $3733 \pm 166$ & $19 \pm 3$ & * \\
\hline
\end{tabular}

* Signal intensity could not be measured.

SRa, Saturation recovery; SE, Spie scho;

SPGR, Spoiled gradient recoiled acquistition in the steady state.

\section{Discussion}

Recent progress in MRI has made possible FAST MR imaging (Martin and Edelman 1990) requiring only $10 \mathrm{sec}$ or less per one scan. Moreover, contrast media for MRI have been developed, although Gd-DTPA is the only clinically available contrast medium for MRI at present. Application of both FAST scan and Gd-DTPA has made dynamic MRI of several organs and tissues possible, especially in brain (Felix et al. 1985), liver (Ohtomo et al. 1987), kidney (Fuchs 1989; Ikehira et al. 1985a, b), spleen (Mirowitz et al. 1991), and colorectal cancer (Curtet et al. 1986). However, the contrast enhancement effect of Gd-DTPA varies according to the pulse sequences used, and Gd-DTPA concentration (Gadian et al. 1985). In x-ray CT or radioisotope scintigraphy, the concentration of contrast medium or radioisotope almost linearly correlates with the CT number or radioactivity, whereas the concentration of Gd-DTPA does not correlate with signal intensity in MRI. The reason is that Gd-DTPA has both a T1 shortening effect and T2 shortening effect. At low concentrations of Gd-DTPA, the T1 shortening effect is dominant, and at high concentrations, the T2 shortening effect 
TABLE 3. Results of tissue concentration of Gd-DTPA by ICP methods after intravenous administration of Gd-DTPA

\begin{tabular}{|c|c|c|c|c|}
\hline No. & $\begin{array}{l}\text { Tissue } \\
\text { type }\end{array}$ & Period $^{\mathrm{a}}$ & $\begin{array}{c}\text { GFR } \\
\left(\mathrm{ml} / \mathrm{min}^{2} /\right. \\
\left.4.48 \mathrm{~m}^{2}\right)\end{array}$ & $\begin{array}{l}\text { Gd-DTPA conc. } \\
\qquad(\mu \mathrm{mol} / \mathrm{g})\end{array}$ \\
\hline 1 & Renal cortex & $5 \min$ & 25 & 0.143 \\
\hline \multirow[t]{2}{*}{2} & Renal cortex & $5 \min$ & 75 & 0.132 \\
\hline & Adipose tissue & $10 \mathrm{~min}$ & & 0.011 \\
\hline \multirow[t]{3}{*}{3} & Renal cortex & $5 \mathrm{~min}$ & 105 & 0.152 \\
\hline & Renal cedulla & $5 \mathrm{~min}$ & & 0.123 \\
\hline & Renal cell cancer & $5 \min$ & & 0.109 \\
\hline \multirow[t]{4}{*}{4} & $\begin{array}{l}\text { Dome of urinary } \\
\text { bladder }\end{array}$ & $\begin{array}{l}4 \mathrm{hr} \& \\
30 \mathrm{~min}\end{array}$ & 95 & 0.012 \\
\hline & Prostate & $\begin{array}{l}4 \mathrm{hr} \& \\
30 \mathrm{~min}\end{array}$ & & 0.013 \\
\hline & Adipose tissue & $6 \mathrm{hr}$ & & 0.026 \\
\hline & Ileum & $10 \mathrm{hr}$ & & 0.011 \\
\hline \multirow[t]{3}{*}{5} & Renal cortex & $5 \min$ & 82 & 0.138 \\
\hline & Renal medulla & $5 \mathrm{~min}$ & & 0.129 \\
\hline & Renal cell cancer & $5 \mathrm{~min}$ & & 0.151 \\
\hline \multirow[t]{3}{*}{6} & Renal cortex & $5 \mathrm{~min}$ & 91 & 0.141 \\
\hline & Renal medulla & $5 \mathrm{~min}$ & & 0.128 \\
\hline & Renal cell cancer & $5 \mathrm{~min}$ & & 0.105 \\
\hline \multirow[t]{3}{*}{7} & Renal conrex & $5 \mathrm{~min}$ & 71 & 0.185 \\
\hline & Renal medulla & $5 \mathrm{~min}$ & & 0.177 \\
\hline & Renal cell cancer & $5 \mathrm{~min}$ & & 0.140 \\
\hline \multirow[t]{3}{*}{8} & Renal cortex & $5 \mathrm{~min}$ & 98 & 0.135 \\
\hline & Renal medulla & $5 \mathrm{~min}$ & & 0.128 \\
\hline & Renal cell cancer & $5 \mathrm{~min}$ & & 0.119 \\
\hline
\end{tabular}

aPeriod is from the injection of Gd-DTPA to sampling of tissue.

is dominant (Weinmann et al. 1984). In the latter condition, signal intensity decreases with increasing Gd-DTPA concentration as shown in our results. Therefore, the ideal contrast medium for positive enhanced MRI should shorten the $\mathrm{T} 1$ value but not change the $\mathrm{T} 2$ value. In comparison with other organs and tissues, the kidney has a marked concentrating effect, is subjected to a "T2 shortening effect", and dynamic MRI of kidney is difficult to interpret. Consequently, knowledge of the concentration of Gd-DTPA in kidney is needed to understand dynamic MRI. There have been several reports on tissue concentration of Gd-DTPA in animals. Gd-DTPA concentrations of rat renal cortex and renal medulla were $1.242 \pm 0.283 \mu \mathrm{mol} / \mathrm{g}$ tissue at $40 \mathrm{sec}$ and $1.975 \pm 0.405 \mu \mathrm{mol} / \mathrm{g}$ tissue at $120 \mathrm{sec}$ after administrattion of Gd-DTPA $0.24 \mathrm{mmol} / \mathrm{kg}$ body weight, respectively (Dean et al. 1988). In rabbits, 1/T1 of kidneys linearly correlated 
with tissue concentration of Gd-DTPA at 5 min after intravenous administration of Gd-DTPA $0.01,0.05$, or $0.1 \mathrm{mmol} / \mathrm{kg}$ (Strich et al. 1985). However, there has been only one report on human brain tissue (Tien et al. 1989), and our report is the first one on the kidney. According to our results, "T2 shortening effect" will not occur in the renal cortex, renal medulla, or renal cell cancer tissue at $5 \mathrm{~min}$ after injection of Gd-DTPA $0.05 \mathrm{mmol} / \mathrm{kg}$ body weight irrespective of whether a low or high magnetic field apparatus is used. On the other hand, according to Aoki et al. (1986), "T2 shortening effect" is the strongest in the rat kidney at 5 to 10 min after injection of Gd-DTPA, and to exclude this "T2 shortening effect", short TR, short TE spin-echo sequences are preferable. This difference between our data and previous animal experiments may be due to differences in the pulse sequences, and dose of Gd-DTPA used. At 5 min after injection of Gd-DTPA, tissue concentration of Gd-DTPA in renal cell cancer was lower than that in normal renal cortex and renal medulla, and so, dynamic MRI at 5 min after injection of Gd-DTPA may be valuable in detecting small renal cell cancer.

In addition to the diagnosis of renal tumor, evaluation of renal function may be one of advantages of dynamic MRI. In evaluationg renal function by dynamic MRI, serial MRI of the same plane are usually taken, and time-intensity curves of the same regions (cortex, medulla etc.) are made. The patterns of dynamic MRI curves are analyzed, and often are compared with patterns of radioisotope renography. Usually, radioisotope renography takes $30 \mathrm{~min}$ or more, and the patterns of radioisotope renography are said to be different from dynamic MRI (Takeda et al. 1990). This difference may be due to the "T2 shortening effect", but, there are no available data on the detailed serial tissue concentrations of Gd-DTPA after injection of Gd-DTPA in man.

The results of our study show several important findings. First, signal intensity linearly correlated with Gd-DTPA concentration from 0 to $2.0 \mu \mathrm{mol} / \mathrm{g}$ with both low and high magnetic field apprarus. Second, with high magnetic field apparatus, signal intensity linearly correlated with Gd-DTPA concentration from 0 to $2.0 \mu \mathrm{mol} / \mathrm{g}$ both under ordinary spin echo sequence and SPGR sequence which is one of gradient-echo sequences. Third, tissue concentration of GdDTPA of kidney at $5 \mathrm{~min}$ after $0.05 \mathrm{mmol}$ Gd-DTPA $/ \mathrm{kg}$ body weight was within the concentration at which signal intensity linearly correlates with Gd-DTPA concentration. Dynamic MRI at $5 \mathrm{~min}$ under ordinary spin echo sequence is actually impossible, and is possible only under FAST scan using high magnetic field apparatus. The last, tissue concentration of Gd-DTPA of renal cortex did not differ according to renal function. This finding showed that dynamic MRI of kidney is possible even in patients with decreased renal function.

Our results also highlighted several problems including tissue concentration of Gd-DTPA in diseased kidneys (hydronephrosis, renovascular hypertension, reflux nephropathy and so on), and tissue concentration of Gd-DTPA within 5 min after administration of Gd-DTPA. These problems require further study. 


\section{Acknowledǵment}

We thank the staff of the Section of Radiology in Niigata Chuo Hospital for performing MRI, and also thank Dr. Meno, Dr. Miyake, and Dr. Awano (Shering Japan Co. Ltd., Osaka, Japan) for measurement of Gd-DTPA concentration by ICP method.

\section{References}

1) Aoki, S., Yoshikawa, K., Itoh, M., Ohtomo, K., Iio, M., Watanabe, N., Niida, T. \& Arada, Y. (1986) Relaxation measurement of Gd-DTPA in rat kidney. Jpn. J. Mag. Res. Med., 6, 129-134.

2) Barbaric, Z.L. (1991) Principles of Genitourinary Radiology. Theime Medical Publishers, Inc., New York, pp. 7-13.

3) Carr, D.H., Brown, J., Leung, W-L. \& Pennock, J.M. (1984) Iron and gadolinium chelates as contrast agents in NMR imaging: Preliminary studies. J. Comput. Assist. Tomogr., n8, 385-389.

4) Curtet, C., Tellier, C. \& Bohy, J. (1986) Selective modification of NMR relaxa-tion time in human colorectal carcinoma by using gadolinium - Diethylenetriaminepentaacetic acid conjugated with monoclonal antibody 19-9. Proc. Natl. Acad. Sci., 83, 4277-4281.

5) Dean, P.B., Miemi, P., Kivisaari, L. \& Kormano, M. (1988) Comparative Pharmacokinetics of Gadolinium DTPA and Gadolinium chloride. Invest. Radiol., 23, Suppl. $1, \mathrm{~s} 258-\mathrm{s} 260$.

6) Edelman, R.R., Shellock, F.G. \& Ahlaids, J. (1990) Practical MRI for the technologist and imaging specialist. In: Clinical Magnetic Resonance Imaging, edited by R.R. Edleman, J.R. Hesselink \& W.B. Saunders, Philadelphia, London, Toronto, Montreal, Sidney, Tokyo, pp. 39-73.

7) Fein, A.B., Lee, J.K.T., Balfe, D.M., Ling, D., Glazer, H.S. \& McClennan, B.L. (1987) Diagnosis and staging of renal cell carcinoma: A comparison of MR imaging and CT. Am. J. Roentgenol., 148, 749-753.

8) Felix, R., Schorner, W., Laniado, M., Niendorf; H-P., Claussen, C., Fiegler, W. \& Speck, U. (1985) Brain tumors: MR imaging with Gadolinium-DTPA. Radiology, 156, 681-688.

9) Fuchs, W.A. (1989) Renal morphology and function in magnetic resonance imaging. In: Morphology and Function in MRI, edited by W.A. Fuchs \& A. Margulis, Splinger-Verlag, Berlin, Heidelberg, New York, London, Paris, Tokyo, pp. 111-131.

10) Gadian, D.G., Payne, J.A., Bryant, D.J., Young, I.R., Carr, D.H. \& Bydder, G.M. (1985) Gdolinium-DTPA as a contrast agent in MR imaging - Theoretical projections and practical observations. J. Comput. Assist. Tomogr., 9, 242-251.

11) Goldman, S.M. \& Gatewood, O.M. ed. (1990) CT and MRI of the Genitourinary Tract. Churchill \& Livingstone, New York, Edinburgh, London, Melbourne.

12) Goldstein, E.J., Burnett, K.R., Hansell, J.R., Casaia, J., Dizon, J., Farrar, B.G., \& Wolf, G.L. (1984) Gadolinium DTPA (an NMR proton imaging contrast agent): Chemical structure, paramagnetic properties and pharmacokinetics. Physiol. Chem. Phys. NMR, 16, 97-104.

13) Hricak, H., Williams, R.D. \& Moon, K.L. (1983) Nuclear magnetic reesonance imaging of the kidney: Renal masses. Radiology, 147, 765-772.

14) Hricak, H., Demas, B.E., Williams, R.D., McNamara, M.T., Hedgcock, M.W., Amparo, E.G. \& Tanagho, E.A. (1985) Magnetic reesonance imaging in the diagnosis and staging of renal and peri renal neoplasm. Radiology, 154, 709-715.

15) Hricak, H., Thonei, R.F. \& Carrol, P.R. (1988) Detection and staging of renal neoplasms: A reassesment of MR imaging. Radiology, 166, 643-649. 
16) Ikehara, H., Yamane, T., Fukuda, N., Torii, S., Shibata, S., Matsumoto, T., Iinuma, T. \& Tateno, Y. (1985a) The trial of the kinetic study for the renal function, using NMR-CT by Gadolinium-DTPA. Jpn. J. Nucl. Med., 22, 219-224.

17) Ikehara, H., Torii, S., Yamane, T., Fukuda, N., Shibata, S., Endoh, M., Matsumoto, T., Sinotou, H., Iinuma, T. \& Tateno, Y. (1985b) The kinetic study for the renal function, using NMR-CT by Gadolinium-DTPA (2) - on regional renogram and non-invasive mesurement of GFR -. Jpn. J. Nucl. Med., 22, 1615-1624.

18) Keevil, S.F., Dolke, G., Brooks, A.P., Armstrong, P., Farthing, M.J.G., Alstead, E.M. \& Smith, M.A. (1992) Proton NMR relaxation times in the normal human liver at 0.08T. Clin. Radiol., 45, 302-306.

19) Kressel, H.Y. (1990) Magnetic Resonance Imaging. In: Clinicam Urography edited by H.M. Pollack \& W.B. Saunders, Philadelphia, London, Toronto, Montreal, Sidney, Tokyo, pp. 433-455.

20) Martin, J. \& Edelman, R.R. (1990) Fast MR imaging. In: Clinical Magnetic Resonance Imaging, edited by R.R. Edleman, J.R. Hesselink \& W.B. Saunders, Philadelphia, London, Toronto, Montreal, Sidney, Tokyo, pp. 183-220.

21) Mirowitz, S.A., Brown, J.J., Lee, J.K.T. \& Heiken, J.P. (1991) Dynamic Gadolinium-enhanced MR imaging of the spleen: Normal Enhancement Pattens and Evaluation of Splenic lesions. Radiology, 179, 681-686.

22) Ohtomo, K., Itai, Y., Yoshikawa, K., Kokubo, T., Yashiro, N., Iio, M. \& Furukawa, K. (1987) Hepatic tumors: Dynamic MR imaging. Radiology, 163, 27-31.

23) Strich, G., Hagan, P.L., Gerber, K.H. \& Slutsky, R.A. (1985) Tissue distribution and magnetic resonance spin lattice relaxation effect of gadolinium-DTPA. Radiology, 154, 723-726.

24) Subramanian, K.S. \& Meranger, J.C. (1982) Simultaneous determination of 20 elements in some human kidney and liver autopsy samples by inductively-coupled plasma emission spectometry. Sci. Total Environ., 24, 147-157.

25) Takeda, M., Katayama, Y. \& Takahashi, H. (1990) Value of dynamic magnetic resonance imaging in hydronephrosis. J. Urol., 143, 258.

26) Tien, R.D., Brasch, R.C., Jackson, D.E. \& Dillon, W.P. (1989) Cerebral ErdheimChester disease: Persistant enhancement with Gd-DTPA on MR images. Radiology, 172, 791-792.

27) Togami, I., Murakami, K., Tsunoda, M., Kitagawa, T., Satoh, N., Kimoto, S., Joja, I., Hiraki, Y., Uno, S., Kumopn, H. \& Ohmori, H. (1991) Evaluation of renal function usng dynamic MRI with Gd-DTPA - Comparison with dynamic CT and renogram using $99 \mathrm{mTc}$-DTPA on normal volunteer-. Jpn. J. Med. Imaging, 10, 138-146.

28) Weinmann, H.J., Brasch, R.C., Press, W.R. \& Wesbey, G.E. (1984) Characteristics of gadolinium-DTPA complex: A potential NMR contrast agent. Am. J. Roentgenol., 142, 619-624. 